\title{
Molecular Identification of Microbial Communities in the Recycled Nutrient Solution of a Tomato Glasshouse Soil-Less Culture
}

\author{
G. Calmin ${ }^{1}$, G. Dennler ${ }^{1}$, L. Belbahri ${ }^{1}$, A. Wigger ${ }^{2}$ and F. Lefort ${ }^{1, *}$
}

${ }^{I}$ Plants and Pathogens Group, Research Institute Earth Nature and Landcaspe, School of Engineering of Lullier, University of Applied Sciences of Western Switzerland, 150 Route de Presinge, 1254 Jussy, Switzerland and ${ }^{2}$ Professionnal Training Centre Nature and Landscape CFPNE, Vegetables Section, 150 Route de Presinge, 1254 Jussy, Switzerland

\begin{abstract}
This study aimed to assess microbial community diversity in recycled nutrient solutions used in soil-less glasshouse cultivation of tomato. One hundred bacterial strains, twenty oomycetes and 6 fungi were isolated and identified through genomic DNA isolation, PCR amplification of the ribosomal DNA region and database interrogations. Similarities of ITS regions with known species ranged from $95 \%$ to $100 \%$. This artificial ecosystem was shown to be microbiologically diverse, since recovered isolate were close to 35 bacterial species, 11 oomycete species and 3 fungal species. Bacteria belonged almost exclusively to $\gamma$-Proteobacteria and Firmicutes, with most represented genera being Bacillus, Acinetobacter, Klebsiella and Serratia. A few bacterial sequences grouped with clones similar to plant and human pathogens, while other isolates could be protective bacteria such as Pseudomonas fluorescens. Oomycetes isolated mostly belonged to the genus Pythium (19 isolates) and were phylogenetically related to common cosmopolitan soil inhabitants or phytopathogenic Pythium species. The six fungal isolates were in 2 genera, Rhizopus and Caesia; Rhizopus isolates were closely related to the post harvest pathogen Rhizopus stolonifer. This original work adds to the efforts of assessing microorganism diversity in recycled nutrient solutions commonly used in glasshouse vegetable production; microbial diversity was high and included potential plant pathogens. This study demonstrated the existence of a wide cultivable microbial community in the nutrient solution before recycling and recirculation and supported the necessity for disinfecting nutrient solutions used in soil-less cultivation systems, during the recycling process, in order to ensure crop sanitation and avoiding plant disease spreading.
\end{abstract}

\section{INTRODUCTION}

Capturing and recycling irrigation runoff is now a common practice in the plant nursery industry, particularly in soil-less crop production, in the wake of environmental concerns and global water scarcity. In soil-less systems glasshouse crops are grown on artificial substrates that are preferred to soil-based media for economic reasons, and because of improved control over water, aeration, nutrition, and root distribution [1]. Traditionally, soil-less culture was operated as drain-to-waste or open systems, in which excess nutrient solutions were allowed to drain to the soil and into groundwater. Crops grown under these conditions were usually irrigated in excess in order to balance both variations in transpiration and nutrient demands of the individual plants and variations within the system in nutrient solution supply to the plants [1-2]. Up to $40 \%$ of the nutrient solution dosed per day might be in excess of crop requirements [3]. However, growers and advisory bodies now recognize that, for environmental and economic reasons, excess nutrient solutions should not be drained to waste, but collected and re-used within closed or re-circulating systems. Closed re-circulating

*Address correspondence to this author at the Plants and Pathogens Group, Research Institute Earth Nature and Landcaspe, School of Engineering of Lullier, University of Applied Sciences of Western Switzerland, 150 Route de Presinge, 1254 Jussy, Switzerland; Tel: +41 2275995 11; Fax: +41 22 75995 27; E-mail: francois.lefort@hesge.ch systems, in addition to promoting sustainability of glasshouse vegetable production, might economically reward growers, with savings in water and fertilizer costs.

Current water recycling methods, however, may return some economically important plant pathogens to irrigation reservoirs from where these organisms can spread further onto the crops. Pathogens of economic significance isolated from irrigation water include bacteria, fungi, nematodes and oomycetes [4]. Among oomycetes, Pythium spp. are more frequent than Phytophthora spp. in irrigation water [5]. Unlike Phytophthora pathogens, however, the potential impacts of Pythium species in irrigation water are poorly understood. This is due to the difficulty in identification of Pythium species and the large, undescribed diversity in this genus [6]. It was also reported in four soilless systems of tomato cultures that bacteria (Pseudomonads) predominated over fungi (Fusarium spp.) and oomycota (Pythium). [7]

There is growing public awareness that fresh or minimally processed fruit and vegetables can be sources of disease-causing bacteria, fungal toxins, viruses, protozoa and helminthes, inspiring new public health and food policies worldwide with an impact on harvesting practices in the soilless crop industry. Contaminated re-circulating nutrient solutions are one important way in which fruit and vegetables may become contaminated with food-borne pathogens or fungal toxins [8]. 
Understanding the microbial community structure in recycled nutrient solutions is essential for understanding microbial processes which underlie secondary contamination of the culture system. In order to reliably characterize the community structure, reliable and rapid qualitative methods, such as rRNA sequencing are required. Little is known of microbial diversity and population structures in recycled nutrient solutions; to date, however, no community structure studies have been carried out using such techniques, although the possibility that plant or human pathogens could contaminate recycled nutrient solution was recognized [9]. This paper reports a first assessment of the diversity of cultivable bacterial, fungal and oomycetes present in a recirculating nutrient solution system, identified using culture on selective media and sequence analysis of main representative isolates in these communities. This study was done in parallel with the evaluation of disinfecting systems of recycled nutrient solution [10]

\section{MATERIALS AND METHODS}

\section{Glasshouse Trials}

Experimental trials in closed soil-less systems were carried out at the Vegetable Crop section of the Professional Training Centre of Lullier (Jussy, Switzerland) during 2005. Tomato plants (hyb. Temptation [Enza Zaden BV, The Netherlands]), 30 days old were grown on Rockwool cubes (Rockwool, Mid-Glamorgan, UK) and transplanted into Rockwool substrate. Plants were maintained on concrete benches with a drip irrigation system (one drip nozzle per plant, flow rate: $2 \mathrm{~L} / \mathrm{h}$ ) in a soil-less culture. General information on water, fertilizers and the nutrient solution used was previously reported [11]. The ultrafiltration system used for disinfecting the recirculating nutrient solution was an ultrafiltration membrane (HYDRAcap, Hydranautics, USA) constituted of polyethersulfone capillaries (inside diam. of $0.8 \mathrm{~mm}$; outside diam. of $1.2 \mathrm{~mm}$; molecular weight cut-off about 100.000-150.000 Daltons) [10].

\section{Chemical Analysis of Nutrient and Recycled Nutrient Solutions}

Nutrient solution and recycled nutrient solution samples from tomato cultures were analyzed for total phosphorus $(\mathrm{P})$, potassium $(\mathrm{K})$, sulphur $\left(\mathrm{SO}_{4}\right)$, calcium $(\mathrm{Ca})$, magnesium $(\mathrm{Mg})$, iron $(\mathrm{Fe})$, manganese $(\mathrm{Mn}), \mathrm{NH}_{4}-\mathrm{N}, \mathrm{NO}_{3}-\mathrm{N}, \mathrm{pH}$ and electro conductivity (EC) at the beginning and after two months of culture Analytical methods used were inductively coupled plasma atomic emission spectroscopy (ICP-AES) for all ions except for $\mathrm{NO}_{3}-\mathrm{N}$ which was assayed by the colorimetric method of Griss. Analysis of $1 \mathrm{~L}$ samples was carried out by SADEF-Pôle d'Aspach (France).

\section{Evaluation of the Cultivable Microbiota in Irrigation Water}

Bacteria, fungi and oomycete counts were obtained after 10 -fold dilution plating on adequate culture media The cultivable bacterial population present in nutrient solution was obtained by passing used nutrient solution $(5 \mathrm{~L})$ through a 47 $\mathrm{mm}$ diam. Durapore ${ }^{\circledR}, 0.22 \mu \mathrm{m}$ pore size membrane. Bacteria present on the filter were then released by vortexing the filter in $2 \mathrm{~mL}$ sterile water in an Eppendorf tube and serial dilution plating on Rose Bengal agar in $90 \mathrm{~mm}$ diam. Petri dishes. Bacteria colonies were counted and checked visually for colony shape and morphology, and DNA was extracted from most bacteria observed in preparation for $16 \mathrm{~S}$ rDNA PCR amplification and sequencing.

The cultivable fungal populations present in nutrient solution was obtained by passing $5 \mathrm{~L}$ of the same solution through a $47 \mathrm{~mm}$ diam. Durapore ${ }^{\circledR}$ membrane, $5.0 \mu \mathrm{m}$ pore size [12]. Spores trapped on the membrane were resuspended by vortexing in $2 \mathrm{~mL}$ sterile water in an Eppendorf tube for $30 \mathrm{~s}$. Aliquots of $100 \mu \mathrm{L}$ of the membrane washing were then spread evenly onto $20 \mathrm{~mL}$ of Potato Dextrose Agar (PDA) ampicillin in a 90-mm diam. Petri dish. Colonies recovered were counted and used in DNA extractions, ITS rDNA amplification and direct sequencing.

The cultivable oomycete population present in nutrient solution waste obtained by filtration of a $5 \mathrm{~L}$ sample of the used nutrient solution through a $5.0 \mu \mathrm{m}$ pore sized membrane and trapped spores re-suspended in water, as described above [12]. Aliquots of $100 \mu \mathrm{L}$ of the membrane washing were spread evenly on $20 \mathrm{~mL}$ of PARP-V8 agar [13], incubated at $23^{\circ} \mathrm{C}$ in the dark and examined daily with a dissecting microscope for mycelial growth. Developing colonies provisionally identified as Pythiaceae species were counted daily in each dish until no new colonies were found. Identities of these colonies were confirmed by examination of morphological traits, based on keys for identifying Phytophthora [13] and Pythium [14].

\section{DNA Extraction and Molecular Identification of Recov- ered Isolates}

Representative colonies recovered from nutrient solution runoff samples were chosen for DNA extraction, internal transcribed spacer of the ribosomal RNA (ITS rDNA) amplification and direct sequencing.

DNA was purified as previously reported [15] and DNA concentration was assessed in a NanoDrop miniaturized spectrophotometer (NanoDrop, USA). Reference identities of the tested bacterial, fungal and oomycete isolates were obtained by genotypic identification through DNA sequencing of target genes amplified by the polymerase chain reaction (PCR) in a Master Gradient thermocycler (Eppendorf, Germany). Bacterial strains were identified by $16 \mathrm{~S}$ rDNA sequencing. 16S rDNA amplification of bacterial samples was carried out using the previously described primers fd1 and $\mathrm{rp} 2$ [16] (Table 1). PCR conditions included an initial denaturation step of $95^{\circ} \mathrm{C}$ for 2 min followed by 35 cycles of $95^{\circ} \mathrm{C}(20 \mathrm{~s}), 42^{\circ} \mathrm{C}(30 \mathrm{~s})$ and $72^{\circ} \mathrm{C}(2 \mathrm{~min})$ terminated with a final $20 \mathrm{~min}$ chain elongation step. All oomycete isolates were identified by ITS1, 5.8S ribosomal gene and ITS2 gene sequencing. ITS amplifications of oomycete samples were carried out using universal primers ITS4 and ITS6 [17] (Table 1). The reaction mixture contained $1 \mathrm{x}$ PCR buffer $(75$ $\mathrm{mm}$ Tris- $\left.\mathrm{HCl}(\mathrm{pH} 9.0), 50 \mathrm{mM} \mathrm{KCl}, 20 \mathrm{mM}\left(\mathrm{NH}_{4}\right)_{2} \mathrm{SO}_{4}\right)$, $0.1 \mathrm{mM}$ dNTPs, $0.25 \mu \mathrm{M}$ of each primer, $1.5 \mathrm{mM} \mathrm{MgCl}_{2}, 1$ $\mathrm{U}$ of Taq Polymerase (Biotools, Spain) and $1 \mu \mathrm{L}$ of mycelial DNA in a total volume of $50 \mu \mathrm{L}$ and the following amplification program was applied: an initial denaturation step of $95^{\circ} \mathrm{C}$ for $2 \mathrm{~min}$ followed by 30 cycles including denaturation for $20 \mathrm{~s}$ at $95^{\circ} \mathrm{C}$, annealing for $25 \mathrm{~s}$ at $55^{\circ} \mathrm{C}$ and extension for 
Table 1. PCR Primers Used in the Study: Oligonucleotide Sequences fd1 and rpe [16], ITS4, ITS5, ITS6 [17] and Location within Genomic DNA

\begin{tabular}{|c|c|c|c|}
\hline Primer & Sense & Sequence (5' $\rightarrow$ 3') & Location \\
\hline \hline ITS4 & Reverse & TCCTCCGCTTATTGATATGC & 28 gene \\
\hline ITS5 & Forward & GGAAGTAAAAGTCGTAACAAGG & 18 gene \\
\hline ITS6 & Forward & GAAGGTGAAGTCGTAA & 18 gene \\
\hline fd1 & Forward & ACGGCTACCTTGTTACGACTT & 16 gene \\
\hline rp2 & Reverse & &
\end{tabular}

$50 \mathrm{~s}$ at $72^{\circ} \mathrm{C}$. Amplification was terminated by a final extension step of $10 \mathrm{~min}$ at $72^{\circ} \mathrm{C}$ [17]. Fungal isolates were processed exactly as described for oomycetes, except that primer ITS5 [17] (Table 1) was used in place of ITS4.

Aliquots of PCR products for all sample types were separated in $1 \%$ agarose (Biofinex, Switzerland) gels in $1 \mathrm{x}$ TBE, at $100 \mathrm{~V}$ for $1 \mathrm{~h}$, stained with ethidium bromide $\left(0.5 \mathrm{mg} \cdot \mathrm{L}^{-1}\right)$ and visualized under UV light. PCR products were purified with the QIAquick PCR purification Kit (Qiagen, Hilden, Germany) and used for direct sequencing (Fasteris SA, Geneva, Switzerland). Ribosomal DNA sequences were compared using BLAST against the GenBank database (NCBI, Bethesda, USA). Identification of isolate to the species or genus level was based on the highest identity scores.

\section{Nucleotide Sequence Accession Number}

DNA sequences of the bacterial, fungal and oomycete isolates from recycled nutrient solutions were registered in GenBank under the following accession numbers DQ190274 - DQ190372 for 100 bacterial isolates, DQ195041 DQ195059 and DQ195066 for 20 oomycete isolates and DQ195060 - DQ195065 for 6 fungi isolates.

\section{Molecular Phylogenies}

Molecular phylogenies of recovered eubacteria and stramenopiles were prepared using a previously published protocol [15-18].

\section{RESULTS}

\section{Recycled Nutrient Solution Constituents}

Chemical analyses of the elements $\mathrm{P}, \mathrm{K}, \mathrm{SO}_{4} \mathrm{Mg}, \mathrm{Fe}$, $\mathrm{NH}_{4}-\mathrm{N}, \mathrm{NO}_{3}-\mathrm{N}, \mathrm{pH}$ and electro conductivity (EC) are shown in Table 2. In tomato cultures, the recycled nutrient solution had higher concentrations of $\mathrm{Ca}, \mathrm{Mg}, \mathrm{Fe}$ and NO3-N and the solution $\mathrm{pH}$ decreased. EC values increased.
Molecular Identification of Cultivable Microbiota in ReCirculating Nutrient Solution

Bacteria, fungi and oomycetes isolated from the recycling nutrient solution were identified by $16 \mathrm{~S}$ rDNA sequencing for bacteria and ITS rDNA sequencing for eukaryotic organisms.

A comparison of the sequence of the PCR products from micro-organisms to those in the GenBank database revealed homologies with many previously characterized strains. In general, most sequences showed 95 - 100\% similarity to the different groups identified (Table 3 ).

After removal of suspected chimeral or poor quality sequences, 100 bacterial, 6 fungal and 21 oomycete sequences were registered in GenBank (Table 3). Bacteria accounted for $79 \%$ and Eukaryota for $21 \%$ of the recovered isolates. Within the Bacteria, Proteobacteria represented $63 \%$ of isolates, Firmicutes $35 \%$, Bacteroidetes $1 \%$ and Actinobacteria $1 \%$. In the Eukaryota, Stramenopiles accounted for $80 \%$ and Fungi $20 \%$ of the recovered strains

Comparison of selected PCR products against the GenBank database showed that bacterial sequences almost exclusively clustered in two eubacterial groups: the $\gamma$ Proteobacteria (63 sequences) and the Firmicutes (33 sequences). One sequence grouped with the bacteriodetes and one with the Actinobacteria.

Most represented genera were Bacillus (30 isolates), Acinetobacter (28 isolates), Klebsiella (6 isolates) and Serratia.(6 isolates). Two main clusters of $\gamma$-Proteobacteria were detected (Fig. 1), representing the Acinetobacter group and a group including Enterobacter, Klebsiella, Serratia, Pectobacterium, Aeromonas and Pseudomonas.

One main cluster Bacillus cluster was also detected in the Firmicutes (Fig. 1).

Table 2. Properties of Initial Nutrient Solution and Recycled Nutrient Solutions Used in the Experiments

\begin{tabular}{|c|c|c|c|c|c|c|c|c|c|c|c|}
\hline Source & pH & $\begin{array}{c}\mathrm{EC} \\
\left(\mathrm{mS} \mathrm{cm}^{-1}\right)\end{array}$ & $\begin{array}{l}\text { Phosphore } \\
\left(\mathrm{mg} \mathrm{liter}^{-1}\right)\end{array}$ & $\begin{array}{l}\text { Potassium } \\
\left(\mathrm{mg} \mathrm{liter}^{-1}\right)\end{array}$ & $\begin{array}{c}\text { Calcium } \\
\left(\mathrm{mg} \mathrm{liter}^{-1}\right)\end{array}$ & $\begin{array}{c}\text { Magnesium } \\
\left(\mathrm{mg} \mathrm{liter}^{-1}\right)\end{array}$ & $\begin{array}{c}\text { Iron } \\
\left(\mathrm{mg} \mathrm{liter}^{-1}\right)\end{array}$ & $\begin{array}{c}\text { Manganese } \\
\left(\mathrm{mg} \mathrm{liter}^{-1}\right)\end{array}$ & $\begin{array}{c}\mathrm{N}-\mathrm{No}_{3} \\
\left(\mathrm{mg} \mathrm{liter}^{-1}\right)\end{array}$ & $\begin{array}{c}\mathrm{N}-\mathrm{NH}_{4} \\
\left(\mathrm{mg} \mathrm{liter}^{-1}\right)\end{array}$ & $\begin{array}{c}\text { Sulfur } \\
\left(\mathrm{mg} \mathrm{liter}^{-1}\right)\end{array}$ \\
\hline Nutrient solution & 6.04 & 2.33 & 37.3 & 298 & 184 & 63 & 1.09 & 0.98 & 253 & 30.9 & 206 \\
\hline Recycled solution & 4.7 & 3.1 & 41.7 & 359 & 292 & 100 & 3.55 & 1.44 & 369 & 30.4 & 326 \\
\hline
\end{tabular}


Table 3. Distribution of the rRNA Sequences 16S from Bacterial Isolates and ITS Sequences from Oomycete and Fungal Isolates Obtained in this Study. The Given Species or Subspecies Represents the Species Showing the Highest Similarity with the Isolated Organism in the Range $95-100 \%$ Identity

\begin{tabular}{|c|c|c|c|c|c|c|c|c|}
\hline Domain & Phyllum & Class & Order & Familly & Genus & Species & Subspecies & $\begin{array}{l}\text { Number } \\
\text { of Strains }\end{array}$ \\
\hline Bacteria & Proteobacteria & Gammaproteobacteria & Pseudomonadales & Moraxellaceae & Acinetobacter & rhizosphaerae & & 1 \\
\hline Bacteria & Proteobacteria & Gammaproteobacteria & Pseudomonadales & Moraxellaceae & Acinetobacter & calcoaceticus & & 9 \\
\hline Bacteria & Proteobacteria & Gammaproteobacteria & Pseudomonadales & Moraxellaceae & Acinetobacter & johnsonii & & 9 \\
\hline Bacteria & Proteobacteria & Gammaproteobacteria & Pseudomonadales & Moraxellaceae & Acinetobacter & genomosp. 3 & & 1 \\
\hline Bacteria & Proteobacteria & Gammaproteobacteria & Pseudomonadales & Moraxellaceae & Acinetobacter & haemolyticus & & 3 \\
\hline Bacteria & Proteobacteria & Gammaproteobacteria & Pseudomonadales & Moraxellaceae & Acinetobacter & venetianus & & 1 \\
\hline Bacteria & Proteobacteria & Gammaproteobacteria & Pseudomonadales & Moraxellaceae & Acinetobacter & junii & & 3 \\
\hline Bacteria & Proteobacteria & Gammaproteobacteria & Pseudomonadales & Moraxellaceae & Acinetobacter & tandoii & & 1 \\
\hline Bacteria & Proteobacteria & Gammaproteobacteria & Pseudomonadales & Pseudomonadaceae & Pseudomonas & putida & & 1 \\
\hline Bacteria & Proteobacteria & Gammaproteobacteria & Pseudomonadales & Pseudomonadaceae & Pseudomonas & fluorescens & & 1 \\
\hline Bacteria & Proteobacteria & Gammaproteobacteria & Pseudomonadales & Pseudomonadaceae & Pseudomonas & monteilii & & 1 \\
\hline Bacteria & Proteobacteria & Gammaproteobacteria & Pseudomonadales & Pseudomonadaceae & Pseudomonas & veronii & & 1 \\
\hline Bacteria & Proteobacteria & Gammaproteobacteria & Aeromonadales & Aeromonadaceae & Aeromonas & hydrophila & & 3 \\
\hline Bacteria & Proteobacteria & Gammaproteobacteria & Enterobacteriales & Enterobacteriaceae & Serratia & marcescens & & 5 \\
\hline Bacteria & Proteobacteria & Gammaproteobacteria & Enterobacteriales & Enterobacteriaceae & Serratia & fonticola & & 1 \\
\hline Bacteria & Proteobacteria & Gammaproteobacteria & Enterobacteriales & Enterobacteriaceae & Klebsiella & planticola & & 1 \\
\hline Bacteria & Proteobacteria & Gammaproteobacteria & Enterobacteriales & Enterobacteriaceae & Klebsiella & oxytoca & & 3 \\
\hline Bacteria & Proteobacteria & Gammaproteobacteria & Enterobacteriales & Enterobacteriaceae & Klebsiella & pneumoniae & & 2 \\
\hline Bacteria & Proteobacteria & Gammaproteobacteria & Enterobacteriales & Enterobacteriaceae & Enterobacter & hormaechei & & 2 \\
\hline Bacteria & Proteobacteria & Gammaproteobacteria & Enterobacteriales & Enterobacteriaceae & Enterobacter & aerogenes & & 4 \\
\hline Bacteria & Proteobacteria & Gammaproteobacteria & Enterobacteriales & Enterobacteriaceae & Enterobacter & cancerogenus & & 1 \\
\hline Bacteria & Proteobacteria & Gammaproteobacteria & Enterobacteriales & Enterobacteriaceae & Enterobacter & amnigenus & & 2 \\
\hline Bacteria & Proteobacteria & Gammaproteobacteria & Enterobacteriales & Enterobacteriaceae & Pectobacterium & carotovorum & carotovorum & 2 \\
\hline Bacteria & Proteobacteria & Gammaproteobacteria & Enterobacteriales & Enterobacteriaceae & Pectobacterium & carotovorum & wasabiae & 1 \\
\hline Bacteria & Proteobacteria & Gammaproteobacteria & Enterobacteriales & Enterobacteriaceae & Pantoea & agglomerans & & 1 \\
\hline Bacteria & Proteobacteria & Gammaproteobacteria & Alteromonadales & Alteromonadaceae & Marinobacter & lipolyticus & & 2 \\
\hline Bacteria & Proteobacteria & Gammaproteobacteria & Enterobacteriales & Enterobacteriaceae & Citrobacter & freundii & & 1 \\
\hline Bacteria & Actinobacteria & Actinobacteridae & Actinomycetales & Micrococcineae & Arthrobacter & nicotianae & & 1 \\
\hline Bacteria & Firmicutes & Bacilli & Bacillales & Bacillaceae & Bacillus & cereus & & 25 \\
\hline Bacteria & Firmicutes & Bacilli & Bacillales & Bacillaceae & Bacillus & thuringiensis & & 4 \\
\hline Bacteria & Firmicutes & Bacilli & Bacillales & Bacillaceae & Bacillus & subtilis & & 1 \\
\hline Bacteria & Firmicutes & Bacilli & Bacillales & Bacillaceae & Lysinibacillus & fusiformis & & 3 \\
\hline Bacteria & Firmicutes & Bacilli & Lactobacillales & Streptococcaceae & Streptococcus & sanguinis & & 1 \\
\hline Bacteria & Firmicutes & Clostridia & Clostridiales & Clostridiaceae & Clostridium & disporicum & & 1 \\
\hline Bacteria & Bacteroidetes & Flavobacteria & Flavobacteriales & Flavobacteriaceae & Chryseobacterium & indologenes & & 1 \\
\hline Eukaryota & Stramenopiles & Oomycetes & Pythiales & Pythiaceae & Pythium & dissotocum & & 3 \\
\hline Eukaryota & Stramenopiles & Oomycetes & Pythiales & Pythiaceae & Pythium & spinosum & & 1 \\
\hline Eukaryota & Stramenopiles & Oomycetes & Pythiales & Pythiaceae & Pythium & pachycaule & & 1 \\
\hline Eukaryota & Stramenopiles & Oomycetes & Pythiales & Pythiaceae & Pythium & diclinum & & 8 \\
\hline Eukaryota & Stramenopiles & Oomycetes & Pythiales & Pythiaceae & Pythium & marinum & & 1 \\
\hline Eukaryota & Stramenopiles & Oomycetes & Pythiales & Pythiaceae & Pythium & coloratum & & 1 \\
\hline Eukaryota & Stramenopiles & Oomycetes & Pythiales & Pythiaceae & Pythium & lutarium & & 1 \\
\hline Eukaryota & Stramenopiles & Oomycetes & Pythiales & Pythiaceae & Pythium & helicoides & & 1 \\
\hline Eukaryota & Stramenopiles & Oomycetes & Pythiales & Pythiaceae & Pythium & aphanidermatum & & 1 \\
\hline Eukaryota & Stramenopiles & Oomycetes & Pythiales & Pythiaceae & Pythium & scleroteichum & & 1 \\
\hline Eukaryota & Stramenopiles & Phaeophyceae & Scytothamnales & & Splachnidium & rugosum & & 1 \\
\hline Eukaryota & Fungi & Mucoromycotina & Mucorales & Mucoraceae & Rhizopus & stolonifer & & 4 \\
\hline Eukaryota & Fungi & Basidiomycota & Agaricomycotina & Polyporales & Postia & subcaesia & & 1 \\
\hline Eukaryota & Fungi & Basidiomycota & Agaricomycotina & Polyporales & Postia & caesia & & 1 \\
\hline
\end{tabular}




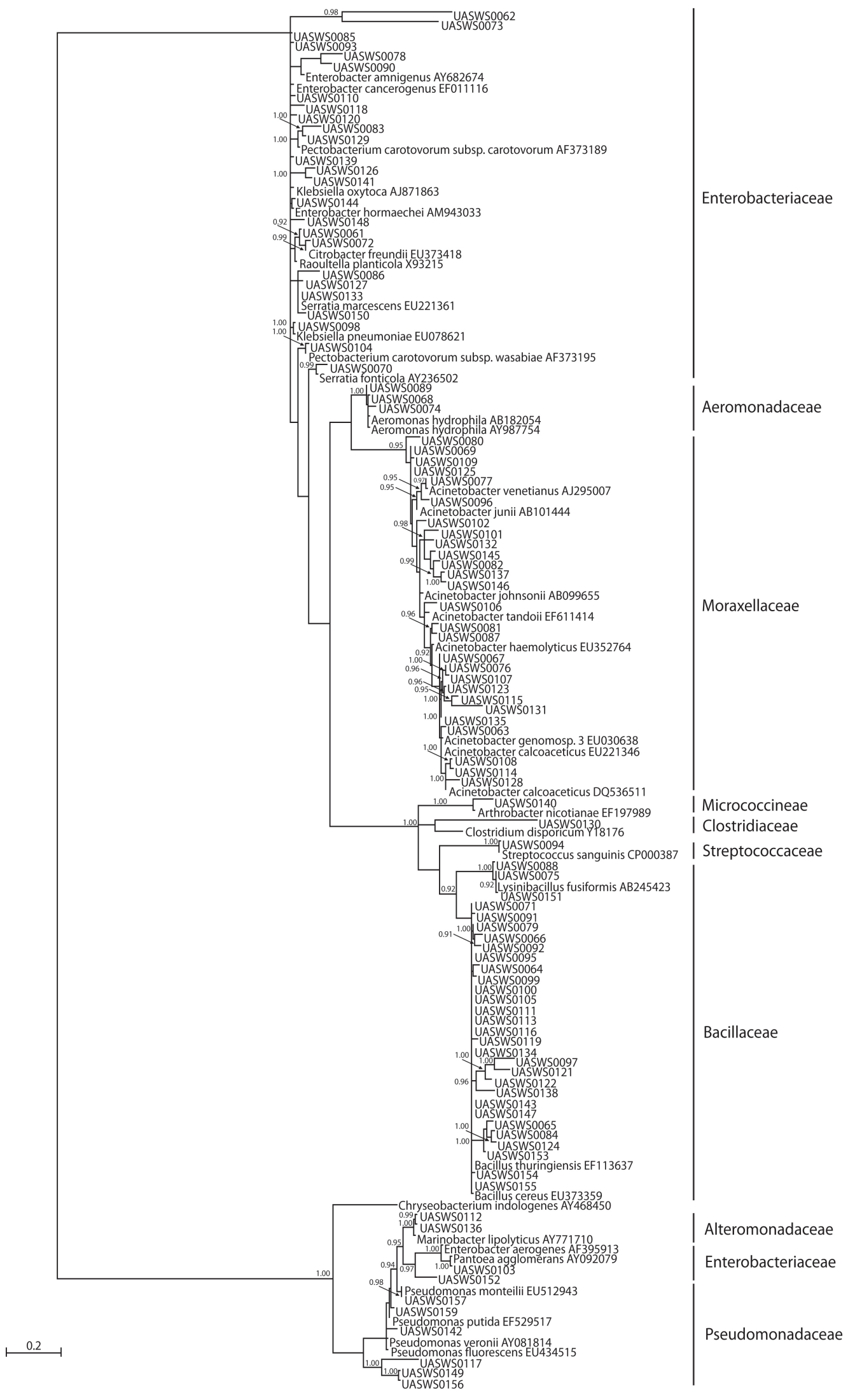

Fig. (1). Bayesian inference (BI) tree showing the relationships among the $16 \mathrm{~S}$ rRNA sequences of the bacterial isolates recovered from recycled nutrient solution. The scale corresponds to 0.2 substitutions per nucleotide position. Values at the different nodes indicate bootstrap support (>0.90) from 2.000.000 generations. 


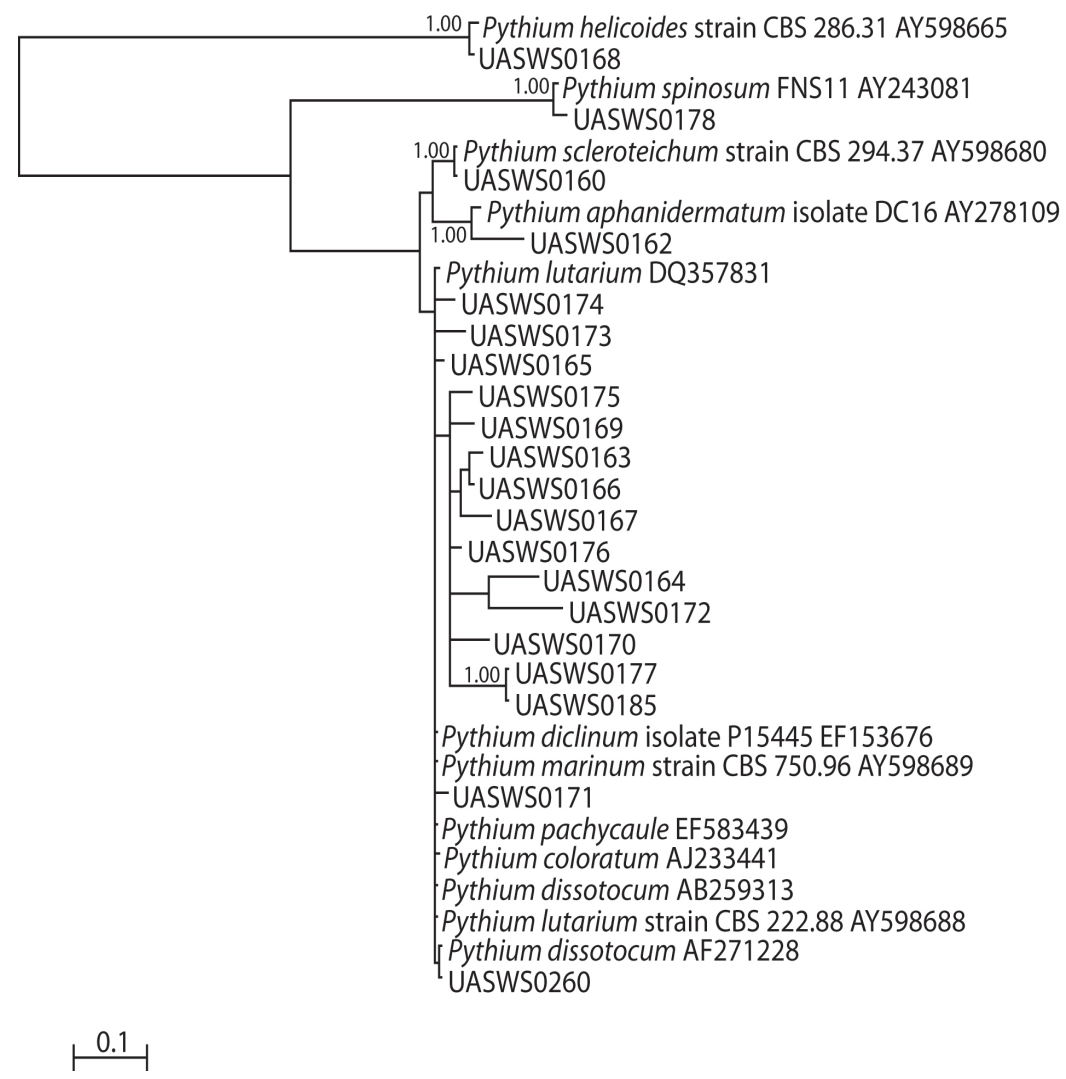

Fig. (2). Bayesian inference (BI) tree showing the relationships among the ITS sequences of Pythium isolates from the recycled nutrient solution. The scale corresponds to 0.1 substitutions per nucleotide position. Values at the different nodes indicate bootstrap ( $>0.90)$ support from 2.000.000 generations.

Out of 20 Stramenopile species isolated, one belonged to the genus Phaeophyceae and 19 to the the Pythium genus (Oomycota). Most abundant isolates showed a 99\% sequence homology with known Pythium, slightly root pathogens as P. dissotocum or known cosmopolitan soil or water inhabitants such as $P$. marinum, $P$. dissotocum, $P$. aquatile, $P$. diclinum and $P$. lutarium. At last one Pythium species was found with homology to $P$. aphanidermatum, one isolate had a very strong sequence (> 99\%) homology with Pythium helicoides and another one with Pythium scleroteichum. Phylogeny of found Pythium is shown on Fig. (2).

Fungi were the less represented organisms and fungal species identified comprised 4 isolates of Rhizopus and 2 of Postia. The Rhizopus isolates grouped with Rhizopus stolonifer, whereas Postia isolates grouped with Postia caesia.

\section{DISCUSSION}

Analyses of the recycled nutrient solution compared with the initial nutrient solution used in the soil-less cultivation of tomato in this work demonstrated clear changes in the concentrations of the different ions investigated, before the disinfected nutrient solution be adapted and recirculated. Such analyses were complemented by measurement of electro conductivity and $\mathrm{pH}$ of the solution. They showed that metal and sulphate concentrations increased in the used nutrient solution. The amounts of total $\mathrm{P}, \mathrm{K}, \mathrm{SO}_{4}, \mathrm{Ca}, \mathrm{Mg}, \mathrm{Fe}, \mathrm{Mn}$, and $\mathrm{N}$ as $\mathrm{NH}_{4}$ or $\mathrm{NO}_{3}, \mathrm{pH}$ and $\mathrm{EC}$ showed considerable variation, which is routinely adapted to optimal nutritional conditions in culture by additions of nutrients to the filtered recycles nutrient solution. The diversity of microbial communities is known to be influenced by the medium composition [19]; it is possible, therefore, that increasing amounts of the measured elements here could impact on microbial community development in soil-less culture systems, favouring more tolerant organisms over sensitive species. This aspect should be further investigated with adequate replications, not carried out in of the course of the present study.

The water from the nutrient recycling system storage tank contained $1.04 \times 10^{5} \mathrm{CFU}$ bacteria $\mathrm{mL}^{-1}$. Some microorganisms could be well adapted to this environment, as supported by other studies demonstrating that metal stress did not always reduce overall productivity or biomass [20].

However, nutrient solution microbiota may have been overlooked in the past, as species discrimination was usually considered a difficult and was mainly conducted by colony morphology observations on selective media. Moreover, opportunistic pathogens may grow slowly or not grow at all on routinely used culture media, consequently escaping detection. Some highly discriminatory technologies, such as mass sequencing of ribosomal RNA, are well suited to profiling microbial populations in re-circulating nutrient solutions and could allow assessment of non cultivable organisms. Direct detection of pathogens by PCR circumvents problems with the morphological identification of the organisms and the production of sexual structures on standard microbiological media. Results obtained here differed from 
previous observations. For instance, in tomato production in four different soilless systems (rockwool, coco peat; and nutrient film technique) [7], bacteria and fungi were assessed by simple colony forming units (cfu) counting. Bacteria were largely predominant over fungi (with Pythium considered as fungi in this study) and Pseudomonads detected by fluorescence represented $20-50 \%$ of counted bacteria. In all systems but the deep flow technique system, Fusarium fungi dominated over Pythium species. In comparison in our coco peat system, bacteria dominated, but Pseudomonas were very rare while prominent genera were Bacillus (30 isolates) and Acinetobacter (28 isolates. Pythium ssp. came second in isolates numbers and fungi were the rarest organisms in the nutrient solution. No Fusarium isolates were recovered. Colony morphology and selective media were also used for isolating fungi (mainly Fusarium and Trichoderma) and oomycete from Gerbera cultures in open and closed soilless systems [21] Other methods have been developed: PCR-DGGE (density gradient gel electrophoresris was used for evaluating bacteria in soilless systems [22]. It proved useful for identifying aerobic cultivable bacteria at low concentrations and showed that bacterial composition and diversity differed between rockwool treatments. Most interesting observations included a shift in the bacterial populations during plant growth and also an important variation in banding pattern, thus in bacterial composition between nutrient solution samples taken from different locations in a closed soilless culture system (drain, effluent, and nutrient solution in rockwool slabs)

The bacteria genera found in the present study belonged mainly to $\gamma$-Proteobacteria (63 isolates), with 3 main genera Acinetobacter (28 isolates), Klebsiella (6 isolates) and Serratia, and to the Firmicutes (33 isolates of which 30 belonged to Bacillus). Lots of these bacteria grouped with bacteria previoulsy observed in lake water and old glacial ice [23-24], coastal marine sediment, sea floor sediment and subsurface and deep sediment [25], activated sewage sludge [26], chemostat enrichments [27], contaminated sediments and soils [28] and the rhizosphere of diverse plants [29]. These cultivable bacteria could be very common constituents of the recycled nutrient solution and might have importance in the ecology of the recycled nutrient solution. Very little are potential pathogens for plants (Pectobacterium carotovorum subsp carotovorum, Arthrobacter nicotianae) or animals (Aeromonas hydrophyla) or humans (Citrobacter freundi, Klebsiella oxytoca, Klebsiella pneumoniae, Raoultella planticola, Serratia marcescens and Streptococcus sanguinis). Potential humans pathogens could certainly be brought into the glasshouse by workers. Acinetobacter which was represented by 28 isolates is a very little known genus of ubiquist bacteria colonising soils, waters, plants, healthy skins of humans and animals [30]. Most unknown Bacillus isolates were close to the entomotoxin producing $B$. thuringiensis and to B. cereus, an ubiquist telluric bacterium known for its implication in food poisoning [31].

The association of some recycled nutrient solution clones with clones observed in polluted sites could suggest that some bacterial species in the recycled nutrient solution are related to a tolerance of high concentration of metal ions. The monitoring of the growth of such species could only be determined by the design and use of specific oligonucleotide probes.
Interestingly $\alpha-, \beta-, \delta-, \varepsilon$-Proteobacteria or Cyanophyceae were not retrieved in the course of this study, which might be explained by the limited coverage of the present probe set [19] which assessed only cultivable organisms.

The experiment revealed a clear abundance of $\gamma$ Proteobacteria and Firmicutes, a pattern which could result from changes in the metal concentration, or other environmental factors, for example, changes in solution temperatures in different parts of the recycling system, or the presence of other organisms reliant on the bacteria as a food source. A previous report suggested that $\gamma$-Proteobacteria were positively correlated to total metal concentrations in a fresh water environment [19]. Other environmental factors, although not studied here, such as the abundance of viruses [32], the protistan grazing pressure [33], or nematode grazing [34], or the plant roots exudates are known to influence the structure of microbial communities and might explain the distribution of the eubacterial groups identified in the present study. As for Pythium spp recovered in this study, most isolates were unknown species close to $P$. lutarium and $P$. marinum, cosmopolitan species found in soils and waters. Only a few isolates displayed a high similarity with known plant pathogens $P$. aphanidermatum, $P$. helicoides, $P$. scleroteichum or P. dissotocum. The rare fungal isolates were allocated for half to the plant pathogen Rhizopus stolonifer. Many environmental variables could thus be implicated in the composition of recycled nutrient solution microbial communities, and thus make it difficult to compare between studies carried in different conditions (substrate, systems, cultivated plants) and to then assess the impacts of all possible variables.

\section{CONCLUSION}

Root diseases and the potential for large scale dissemination of plant pathogens are major limiting factors affecting the use of recycled nutrient solutions. Disinfecting recycling solutions through different filtering systems is known to be effective for removing most microorganisms from recycling solutions [10]. Identification of micro-organisms present in recycled nutrient solutions supported that disinfection prior to the recycling and recirculating process would be required in order to produce quality plants and plant products.

This assessment of the microbial community in a recycled nutrient solution from a tomato culture showed a wide diversity of cultivable micro-organisms. Most of the isolated species were not known before. A few of them however showed a high similarity to some plant or animal pathogens highlighting the necessity for disinfecting recycled nutrient solutions. A few others could be advantageous and protecting organisms. This work could be further enhanced by studying the evolution of total microbiota species, cultivable and not cultivable, in course of culture and in function of the evolution of the chemical composition of the recycled solution.

\section{ACKNOWLEDGEMENTS}

This work was financially supported by the Strategical Research Fund of the University of Applied Sciences of Western Switzerland, Rossat SA (Payerne, Switzerland) and Membratec SA (Sierre, Switzerland). 


\section{REFERENCES}

[1] Resh HM. Hydroponic food production: A definitive guidebook for the advanced home gardener and the commercial hydroponic grower $6^{\text {th }}$ ed. CRC Press, Boca. Raton, FL 2002.

[2] Pardossi A, Malorgio F, Incrocci L, et al. Simplified models for the water relations of soilless cultures: what they do or suggest for sustainable water use in intensive horticulture? In: IIIrd International Symposium on models for plant growth, environmental control and farm management in protected cultivation (HortiModel 2006). Acta Hortic 2006; 718: 425-34.

[3] McPherson GM, Harriman MR, Pattison D. The potential for spread of root diseases in recirculating hydroponic systems and their control with disinfection. Med Fac Landbouww Univ Gent 1995; 60: 71-9.

[4] Stanghellini ME, Rasmussen SL. Hydroponics : a solution for zoosporic pathogens. Plant Dis 1994; 78(12): 1129-38.

[5] Ali-Shtayeh MS, MacDonald JD, Kabashima J. A method for using commercial ELISA tests to detect zoospores of Phytophthora and Pythium species in irrigation water. Plant Dis 1991; 75: 305-11.

[6] Lévesque CA, de Cock AWAM. Molecular phylogeny and taxonomy of the genus Pythium. Mycol Res 2004; 108: 1363-83.

[7] Koohakana P, Ikeda H, Jeanaksorn T, et al. Evaluation of the indigenous microorganisms in soilless culture: occurrence and quantitative characteristics in the different growing systems. Sci Hortic 2004; 101(1-2): 179-88.

[8] Steele M, Odumeru J. Irrigation water as source of foodborne pathogens on fruit and vegetables. J Food Prot 2004; 67: 2839-49.

[9] Stanghellini ME, Kim DH, Rasmussen SL, Rorabaugh PA. Control of root rot of peppers caused by Phytophthora capsici with a nonionic surfactant. Plant Dis 1996; 80: 1113-6.

[10] Belbahri B, Dennler G, Calmin G, Wigger A, Lefort F. Assessing efficacy of ultrafiltration and biofiltration systems used in soilless production through molecular detection of Pythium oligandrum and Bacillus subtilis as model organisms. Acta Hortic 2007; 747: 97105.

[11] Garibaldi A, Minuto A, Grasso V, Gullino ML. Application of selected antagonistic strains against Phytophthora cryptogea on gerbera in closed soilless systems with disinfection by slow sand filtration. Crop Prot 2003; 22: 1053-61.

[12] Hong CX, Richardson PA, Kong P. Comparison of membrane filters as a tool for isolating Pythiaceous species from irrigation water. Phytopathology 2002; 92: 610-6.

[13] Erwin DC, Ribeiro KO. Phytophthora Diseases Worldwide. The American Phytopathological Society, St. Paul, MN 1996.

[14] Dick MW. Keys to Pythium. University of Reading Press, Reading, UK 1990.

[15] Belbahri L, Calmin G, Sanchez-Hernandez E, Oszako T, Lefort F. Pythium sterilum sp. nov. isolated from Poland, Spain and France, its morphology and molecular phylogenetic position. FEMS Microbiol Lett 2006; 255(2): 209-14.

[16] Weisburg WG, Barns SM, Pelletier DA, Lane DJ. 16S ribosomal DNA amplification for phylogenetic study. J Bacteriol 1991; 173: 697-703.

[17] Cooke DEL, Drenth A, Duncan JM, Wagels G, Brasier CM. A molecular phylogeny of Phytophthora and related oomycetes. Fung Genet Biol 2000; 30: 17-32.
[18] Belbahri L, Calmin G, Pawlowski J, Lefort F. Phylogenetic analysis and real time PCR detection of downy mildew pathogen of sweet basil and sage plants reveal a new species in the Peronospora genus. Mycol Res 2005; 109 (11): 1276-387.

[19] Ravenschlag K, Sahm K, Amann R. Quantitative molecular analysis of the microbial community in marine arctic sediments (Svalbard). Appl Environ Microbiol 2001; 67: 387-95.

[20] Shi W, Becker J, Bischoff M, et al. Association of microbial community composition and activity with lead, chromium, and hydrocarbon contamination. Appl Environ Microbiol 2002; 68: 3859-66.

[21] Grasso V, Minuto A, Garibaldi A. Selected microbial strains suppress Phytophthora cryptogea in gerbera crops produced in open and closed soilless systems. Phytopathol Mediterr 2003; 42: 55-64.

[22] Postma J, Lankwarden JBL, van Elsas JD. Molecular fingerprinting of microbial populations in soilless culture systems. Acta Hortic 2001; 548: 537-42.

[23] Hiorns WD, Methé BA, Nierzwicki-Bauer SA, Zehr JP. Bacterial diversity in Adirondack Mountain lakes as revealed by 16S rRNA gene sequences. Appl Environ Microbiol 1997; 63: 2957-60.

[24] Christner BC. Recovery of bacteria from glacial and subglacial environments. Ph.D. Thesis. Ohio State University, Columbus 2002.

[25] Mills HJ, Martinez RJ, Story S, Sobecky PA. Identification of members of the metabolically active microbial populations associated with Beggiatoa species mat communities from Gulf of Mexico cold-seep sediments. Appl Environ Microbiol 2004; 70: 5447-58.

[26] Carr EL, Kampfer P, Patel BK, et al. Seven novel species of Acinetobacter isolated from activated sludge. Int $\mathrm{J}$ Syst Evol Microbiol 2003; 53: 953-63.

[27] Watanabe K, Teramoto M, Futamata H, Harayama S. Molecular detection, isolation and physiological characterization of functionally dominant phenol-degrading bacteria in activated sludge. Appl Environ Microbiol 1998; 64: 4396-402.

[28] Fredrickson JK, Zachara JM, Balkwill DL, et al. Geomicrobiology of high-level nuclear waste-contaminated vadose sediments at the Hanford site, Washington state. Appl Environ Microbiol 2004; 70: 4230-41.

[29] Filion M, Hamelin RC, Bernier L, St-Arnaud M. Molecular profiling of rhizosphere microbial communities associated with healthy and diseased black spruce (Picea mariana) seedlings grown in a nursery. Appl Environ Microbiol 2004; 70: 3541-51.

[30] Daniel BO, Pernthaler J, Schramm A, Amann R, Raskin L. Monitoring precursor $16 \mathrm{~S}$ rRNAs of Acinetobacter spp. in activated sludge wastewater treatment systems. Appl Environ Microbiol 2000; 66: 2154-65.

[31] Ahmed R, Sankar-Mistry P, Jackson S, Ackermann H-W, Kasatiya SS. Bacillus cereus phage typing as an epidemiological tool in outbreaks of food poisoning. J Clin Microbiol 1995; 33(3): 636-40.

[32] Weinbauer MG, Rassoulzadegan F. Are viruses driving microbial diversification and diversity? Environ Microbiol 2004; 6: 1-11.

[33] van Hannen EJ, Mooij W, van Agterveld MP, Gons HJ, Laanbroek HJ. Detritus-dependent development of the microbial community in an experimental system: qualitative analysis by denaturing gradient gel electrophoresis. Appl Environ Microbiol 1999; 65: 2478-84.

[34] De Mesel I, Derycke S, Moens T, et al. Top-down impact of bacterivorous nematodes on the bacterial community structure: a microcosm study. Environ Microbiol 2004; 6: 733-44. 